N. V. KUZMINOVA', A. V. IVANKOVA ${ }^{1}$, V. P. IVANOV ${ }^{2}$, S. E. LOZINSKY (Vinnytsia, Ukraine)

\title{
DIAGNOSTIC AND PROGNOSTIC VALUE OF CYSTATIN C AS AN EARLY MARKER OF RENAL DYSFUNCTION IN PATIENTS WITH CARDIOVASCULAR PATHOLOGY
}

\author{
'Department of Internal Medicine № 1, Vinnytsia National Pirogov Memorial Medical University; \\ ${ }^{2}$ Department of Internal Medicine № 3, Vinnytsia National Pirogov Memorial Medical University; \\ ${ }^{3}$ Department of Internal Medicine of the Medical Faculty № 2, Vinnytsia National Pirogov Memorial \\ Medical University <kuzminova5517@gmail.com>
}

\begin{abstract}
Disorders of the kidneys often occur in cardiovascular diseases. They are connected with the heart by complex hemodynamic and neuroendocrine bonds. The structure, functions, and possibilities of using an endogenous indicator of the functional state of the kidney cystatin $C(C y s C)$ are discussed in the article. Available data allow the use of Cys $C$ as a predictor of renal dysfunction in patients with cardiovascular pathology and arterial hypertension, in particular. However, the widespread use of Cys $C$ in routine clinical practice requires further study and improvement.
\end{abstract}

Key words: cystatin C; glomerular filtration rate; creatinine; cardiorenal syndrome; cardiovascular risk; cardiovascular disease; heart failure; stroke; ischemic heart disease; diabetes mellitus; arterial hypertension.

Introduction. There are complex hemodynamic and neuroendocrine bonds between the heart and the kidneys, which unite them into a single functional system. It provides support for adequate blood pressure (BP), the volume of circulating blood and electrolyte balance $[6,8,9]$. Therefore, it is not surprising that under the condition of acute or chronic dysfunction of one of these organs there is an acute or chronic dysfunction of another.

In order to evaluate the functional status of the kidneys, clinical definition of glomerular filtration rate (GFR) is most often used in clinical practice, but its reduction only occurs when the number of functioning nephrons decreases, therefore it cannot serve as an early marker of kidney damage, which became the prerequisite for the search for more sensitive diagnostic methods [39].

Cystatin $\mathrm{C}$ (Cys $\mathrm{C}$ ) is being actively studied today as the early and most informative marker of renal dysfunction. Cys $\mathrm{C}$ is freely filtered through the glomerular membrane, due to its low molecular weight. Because of this, the level of this indicator is relatively stable in the system circulation. It has been shown that Cys Cis a more sensitive indicator of GFR lowering than creatinine because it is not influenced by such factors as age, gender, muscle mass, nutritional characteristics, physical activity, race. At the same time, it serves as an effective marker for early detection of a renal failure, even at normal creatinine levels $[1-3,44]$. It is these properties that allow us to consider Cys $\mathrm{C}$ as an indicator that reflects the function of the kidneys in different categories of patients. The special diagnostic value of Cys $\mathrm{C}$ is obtained in pediatrics, patients with diabetes mellitus, patients with acute kidney damage, and patients with cardiovascular (CV) diseases.

Structure and functions of cystatin C. Cystatin C (Cys C) is an endogenous indicator of glomerular filtration rate, which has very interesting features. Cys $\mathrm{C}$ is a basic peptide consisting of 122 amino acid residues with a molecular weight of about $13 \mathrm{kDa}$. It is an important extracellular inhibitor of cysteine proteases that belong to the second type of cysteine superfamily. Two other representatives of such inhibitors that were found in mammals were called cystatins $\mathrm{A}$ and $\mathrm{B}[5,31,35]$.

An active and mature form of $\mathrm{Cys} \mathrm{C}$ in humans is called Cys $\mathrm{C}$-monomer and consists of one non-glycosylated polypeptide chain, the individual links of which are interconnected by disulfide bridges. Cys C-monomer is present in virtually all fluids in the 
body, but its largest number is found in cerebrospinal fluid, milk, and sperm. Interestingly, the concentration of Cys $\mathrm{C}$ in the cerebrospinal fluid is about 5.5 times higher than in the serum. Also, the level of this peptide can be determined in urine and saliva [5].

CysC is produced by virtually all cells in the body containing the nucleus. The sustainability of Cys C products, as well as other similar inhibitors, protects the body from uncontrolled activation of proteolysis. Cys $\mathrm{C}$ products are considered to be practically independent of such factors as inflammation, age, sex, muscle mass, tumor growth and degree of hydration of the organism $[10,16]$.

It is believed that the elimination of Cys C by $99 \%$ is done by the kidneys. Cys $\mathrm{C}$ is freely filtered in glomerular capillaries, and since its molecule is not exposed to either tubular reabsorption or secretion, it can be considered almost a perfect marker of GFR. The concentration of Cys $\mathrm{C}$ in serum should be inversely related to the size of the GFR since when it enters the tubular space during reabsorption, Cys $\mathrm{C}$ is almost completely metabolized in the proximal convulsive tubule $[14,18,20]$.

The notion of the cardiorenal syndrome, the role of cystatin $\mathbf{C}$ in the prediction of cardiovascular death. The close relationship between the CV system and the kidneys is well-known. The relationship between dysfunction of the kidneys and the CV system is multifaceted and is based on the type of feedback. In this context, the kidney can act as a target organ and take an active part in the formation of systemic metabolic and vascular pathological processes. Violation of the functioning of any link leads to the activation of the renin-angiotensin-aldosterone system and sympathetic hyperactivation, the development of endothelial dysfunction and chronic systemic inflammation. Thus, the complex pathogenetic circle closes, resulting in the progression of cardiac and kidney dysfunction, myocardial and vascular remodeling, and the increase in morbidity and mortality. This pathophysiological state in modern medicine was called the cardiomorphic continuum [7, 27].

Since the cardiorenal syndrome is ambiguous, in 2010 a group of researchers from the Acute Dialysis Quality Initiative Group (ADQI) published a conciliation document, "Cardiorenal Syndromes", highlighting 5 main types according to the nature and primary severity of heart or kidney damage $[4,9,44]$ :

- type 1 (acute cardiorenal) - acute deterioration of the heart function causes the development of acute renal failure;

- type 2 (chronic cardiorenal) - chronic pathology of the CV system causes the development and progression of chronic renal failure;

- type 3 (acute renocardial) - acute renal dysfunction causes acute cardiovascular damage;

- type 4 (chronic renocardial) - chronic renal dysfunction (chronic kidney disease) leads to deterioration of the function of the heart, myocardial hypertrophy and/or increased risk of CV catastrophes;

- type 5 (secondary) - the deterioration of the kidney function and the CV system occurs in parallel and has the same cause of development.

In this context, the importance of GFR becomes important, which decrease should be considered as an independent risk factor for the development and progression of cardiovascular pathology and mortality [4].

In a series of large population studies, it has been shown that even initial renal impairment, when the serum creatinine level is within normal range or slightly elevated, is accompanied by a sharp increase in CV morbidity and mortality [36]. The results of a number of other studies have confirmed that the deterioration of the functional state of the kidneys in patients with hypertension was associated with a deterioration of the CV prediction $[30,45]$. In a series of meta-analyses, which included hundreds of thousands of cases, a critical level of GFR was identified, at which the risk of cardiovascular and total mortality was about $75 \mathrm{ml} / \mathrm{min} / 1.73 \mathrm{~m}^{2}$ [14].

Such data prompted researchers to detection and detailed study of earlier markers of renal dysfunction, one of which is Cys C. In many studies, a correlation was found 
between the increase in serum Cys Cor the values of GFR, calculated on its basis, and the incidence of cardiovascular events [14, 15, 18-22, 28, 43, 47, 48, 50].

An analysis of the results of the NHANES III study showed that Cys C was associated with overall mortality in men belonging to medium-high coronary risk groups and cardiovascular mortality in women with low-risk [51].

MESA and CHS studies involving around 12,000 people showed that the evaluation of GFR only on the basis of Cys $\mathrm{C}$ proved to be a more reliable predictor of cardiovascular mortality than the determination of this parameter based on creatinine or the combined use of Cys $\mathrm{C}$ and serum creatinine [40].

The AtheroGene study, which involved approximately 1,900 people with ischemic heart disease and GFR $\leq 60 \mathrm{ml} / \mathrm{min} / 1.73 \mathrm{~m}^{2}$, showed that Cys $\mathrm{C}$ was a reliable predictor of cardiovascular death, regardless of classical or nonclassical coronary risk factors. In this case, serum creatinine did not depend on the effects of coronary heart disease [26].

In chronic kidney disease of 3 and 4 stages of non-diabetic etiology, Cys $\mathrm{C}$ also proved to be a predictor of cardiovascular lethality. Interestingly, its prognostic value was even slightly higher than the GFR, which was detected by the clearance of iothalamate [34].

Cystatin $\mathbf{C}$ and arterial hypertension. Higher levels of Cys $\mathrm{C}$ were associated with the presence of arterial hypertension in adults without clinical manifestations of chronic kidney disease, which was confirmed in a large American population study. However, this dependence was observed only in women [46]. In patients with hypertension, the serum Cys $\mathrm{C}$ level correlated with albuminuria, left ventricular myocardial mass index, intima of the general carotid artery and the mean systolic blood pressure (measured by daily monitoring) [49]. The abovementioned data allow us to consider Cys $\mathrm{C}$ as a sensitive marker for the severity of heart and kidney damage in essential hypertension.

In addition, in hypertensive patients with coronary heart disease, $\mathrm{Cys} \mathrm{C}$ is associated with severity of coronary artery disease, homocysteine levels in plasma and traditional risk factors. It was also found that Cys $\mathrm{C}$ serves not only a marker of renal dysfunction but also a marker of chronic inflammation in patients with hypertension $[17,18,37,38]$.

According to the data of the daily monitoring, it was also found that the level of Cys C closely correlates with the values of systolic, diastolic and pulsed AP and the level of albuminuria. These data also indicated that even at the early stages of hypertension Cys C or GFR, calculated on its basis, were the best predictors of the appearance of microalbuminuria than creatinine clearance or GFR, calculated on its basis [22, 27, 33, 38].

Important is the fact that in patients with hypertension, the concentration of serum Cys $\mathrm{C}$ was directly related to the severity of myocardial hypertrophy. In this case, there was no reliable relationship between creatinine and GFR calculated on its basis and characteristics of myocardial remodeling. Also, in the case of primary hypertension, a clear association was found between Cys $C$ with the index of renal vascular resistance [37, 41, 42].

The role of Cys $\mathrm{C}$ in predicting stroke development is controversial and requires further research. However, there is a large-scale meta-analysis, which includes more than 22,000 cases, in which the high level of Cys $\mathrm{C}$ is clearly a reliable and independent marker for stroke [29]. A large Chinese study, which included 3,348 patients with acute ischemic stroke, showed that a low GFR level combined with a low LDL level $\geq 4.14 \mathrm{mmol} / \mathrm{l}$, was a predictor of adverse events throughout the year in this category of patients [53].

Cystatin $C$ in ischemic heart disease. In patients with myocardial infarction in the acute phase, the concentration of Cys $\mathrm{C}$ in blood plasma was significantly higher than in patients with stable or unstable angina pectoris. In addition, with further followup for 6 months, the development of cardiovascular complications was associated with higher levels of Cys C in plasma [20].

Also, the prognostic significance of Cys C was evaluated in 726 patients with or suspected acute coronary syndrome without elevation of the ST segment. The develop- 
ment of myocardial infarction or death was assessed after 40 days and 6 months. The high level of Cys $C$ proved to be a reliable predictor of the lethal outcome, but not the development of myocardial infarction [25]. But there is another work involving 1,128 people with acute coronary syndrome without elevation of the $S T$ segment, but with an elevated level of troponin $\mathrm{T}$, in which there is a clear link between the concentration of Cys $\mathrm{C}$ and the development of myocardial infarction over the next 3 years [50].

Taglieri N. and co-authors observed patients with acute coronary syndrome without elevation of the ST segment throughout the year and found that high levels of Cys C correlated with a higher incidence of cardiovascular death, nonfatal myocardial infarction, and unstable angina pectoris. In this case, GFR (calculated according to the MDRD formula) or creatinine was not an independent predictor of negative cardiovascular events in this category of patients [48]. In patients with acute coronary syndrome with an elevation of the segment of $S T$, an elevated Cys C level might suggest a greater likelihood of further hospitalizations for congestive heart failure. In this category of patients, Cys C was also a predictor of the development of left ventricular dysfunction within 6 months of post-myocardial infarction $[15,23]$.

Cys $\mathrm{C}$ was also a significant predictor of coronary events even in patients without cardiovascular diseases, which was confirmed in a large Swedish MDC study, which involved more than 5,000 people [32].

Cystatin $\mathbf{C}$ as a predictor of heart failure development. There are a number of studies in which there is a close relationship between the level of serum Cys $C$ and the development of heart failure. For the first time, the scientists stated this based on the Cardiovascular Health Study. Cys C proved to be a more accurate indicator of the probability of occurrence of heart failure than creatinine, especially in those surveyed with normal kidney function. Therefore, Cys $\mathrm{C}$ can serve as an independent predictor of heart failure in people without chronic kidney disease, whereas the GFR calculated by the MDRD does not have such prognostic capabilities [47].

The results of the Physicians' Health Study have shown that elevated Cys C levels were associated with an increased risk of developing heart failure, but this relationship was clearly seen only in people with arterial hypertension [17].

Interestingly, increasing the concentration of Cys $\mathrm{C}$ with approximately equal reliability involves undesirable clinical consequences in patients with the presence or absence of microalbuminuria, suggesting the presence of other mechanisms, and not just an increase in the excretion of albumin in the urine.

Cystatin $\mathrm{C}$ and diabetes mellitus. Cys $\mathrm{C}$ is also gaining tremendous value in patients with diabetes, as it helps to detect renal dysfunction earlier than all available methods in clinical practice for evaluating this condition (even earlier than microalbuminuria) $[11,13,24,52]$. An important feature of Cys $\mathrm{C}$ is that it is capable to react to fast transient changes in GFR, which are particularly characteristic of type 1 diabetes [12]. Also, this indicator allows to predict the appearance of arterial hypertension in patients with diabetes and, to some extent, to assess the progression of coronary atherosclerosis in these patients [30,45].

Conclusions. Due to its unique properties (independence from anthropometric, gender, age factors and comorbid conditions), serum levels of $\mathrm{CysC}$ should be considered as:

- practically the ideal marker of GFR, which allows to predicted its decrease before creatinine;

- a significant predictor of damage to target organs (heart and kidneys) in patients with hypertension;

- an accurate and powerful indicator of prediction of cardiovascular events;

- the earliest biomarker of kidney damage, which allows administeringtimely a renoand cardioprotective therapy in patients with CV pathology and diabetes mellitus.

Prospects for further research. It is expedient to have a more in-depth study of the properties of Cys $\mathrm{C}$ in various pathological conditions, which can help to identify early kidney damage and prevent the development of renal failure and other complications. 


\section{R e f e r e n c e s}

1. Вельков B. В. Цистатин С: точный индикатор скорости клубочковой фильтрации, ранний маркёр преэклампсии // Лаборатория. -2010 . - № 10. - С. 18-22.

2. Визир В. А. Кардиоренальный синдром // Артериальная гипертензия. - 2011. Вып. 16, № 2. - С. 100-109.

3. Вороненко Ю. В. Актуальні питання нефрології в практиці сімейного лікаря // Ciмейна медицина. - 2015. - № 7. - С. 64-87.

4. Іванов В. П., Савіцьька Ю. В., Іванкова А. В. Кардіоренальний звязок, діагностичне та прогностичне значення натрійуретичних пептидів за систолічної хронічної серцевої недостатності // Кардиология от науки к практике. - 2016. - Вип. 23, № 4. - С. 69-80.

5. Каюков И. Г., Смирнов А. В., Эмануэль В. Л. Цистатин С в современной медицине // Hефрология. - 2012. - Вип. 16, № 1. - С. 22-39.

6. Коваленко В. Н., Гавриш А. С. Ишемическая кардиомиопатия: нейрогуморальные и иммуновоспалительные аспекты пато- и морфогенеза // Укр. кардіол. журн. 2014. - № 4. - C. 14-19.

7. Курята А. В., Черкасова А. В. Артериальная гипертензия при хронической болезни почек: Монографія. - Дніпро: ДМА МОЗ України, 2015. - С. 3-10.

8. Сиволап В. Д., Лашкул Д. А. Маркери фіброзу міокарда та функція нирок у хворих на хронічну серцеву недостатність ішемічного генезу з фібриляцією передсердь // Укр. мед. часопис. - 2015. Вип. 107, № 3. - С. 77-79.

9. Харченко Е. П. Сердечная недостаточность при кардиоренальных синдромах // Терапевт. арх. - 2015. - № 1. - C. 85-91.
1. Vel'kov V. V. Cistatin S: tochnyj indikatorskorosti klubochkovoj fil'tracii, rannij marker preehklampsii // Laboratoriya. - 2010. № 10. - S. 18-22.

2. Vizir V. A. Kardiorenal'nyj sindrom // Arterial'naya gipertenziya. - 2011. Vyp. 16, № 2. - S. 100-109.

3. Voronenko Yu.V.Aktual'nipitannyanefrologii v praktici simejnogo likarya // Simejna medicina. - 2015. - № 7. - S. 64-87.

4. Ivanov V. P., Savic'ka Yu. V., Ivankova $A$. V. Kardiorenal'nij zv'yazok, diagnostichne ta prognostichne znachennya natrijuretichnih peptidiv za sistolichnoï hronichnoï sercevoï nedostatnosti // Kardiologiya ot nauki k praktike. - 2016. - Vip. 23, № 4. - S. 69-80.

5. Kayukov I. G., Smirnov A. V., Ehmanuehl'V. L. Cistatin $\mathrm{S}$ v sovremennoj medicine // Nefrologiya. - 2012. - Vip. 16, № 1. - S. 22-39.

6. Kovalenko V. N., Gavrish A. S. Ishemicheskaya kardiomiopatiya: nejrogumoral'nye i imunnovospalitel'nye aspekty pato- i morfogeneza // Ukr. kardiol. zhurn. - 2014. № 4. - S. 14-19.

7. KuryataA. V., CHerkasovaA. V.Arterial'naya gipertenziya pri hronicheskoj bolezni pochek: Monografiya. - Dnepr: DMA MOZ Ukraïni, 2015. - S. 3-10.

8. Sivolap V. D., Lashkul D. A. Markeri fibrozu miokarda ta funkciya nirok u hvorih na hronichnu sercevu nedostatnist' ishemichnogo renezu z fibrilyacieyu peredserd'// Ukr. med. chasopis. - 2015. - Vip. 107 , № 3. - S. 77-79.

9. Harchenko E. P. Serdechnaya nedostatochnost' pri kardiorenal'nyh sindromah // Terapevt. arh. -2015 . - № 1. - S. 85-91.

10. Bansal N., Zelnick L.R., Alonso A. et al. eGFR and Albuminuria in Relation to Risk of Incident Atrial Fibrillation: A Meta-Analysis of the Jackson Heart Study, the Multi-Ethnic Study of Atherosclerosis, and the Cardiovascular Health Study // Clin. J. Am. Soc. Nephrol. - 2017. - Vol. 12, N 9. - P. 1386-1398. doi: 10.2215/CJN.01860217.

11. Borges R. L., Hirota A. H., Quinto B. M. et al. Iscystatin Causefulmarkerin the detection of diabetickidneydisease? // Nephron. Clin. Pract. - 2010. - Vol. 1142. - P. 127-134.

12. Cherney D. Z., Sochett E. B., Dekker M. G., Perkins B. A. Ability of cystatin C to detect acute changes in glomerular filtration rate provoked by hyperglycaemia in uncomplicated Type 1 diabetes // Diabet. Med. - 2010. - Vol. 27, N 12. - P. 1358-1365.

13. Chudleigh R. A., Ollerton R. L., Dunseath G. et al. Use of cystatin C-based estimations of glomerular filtration rate in patients with type 2 diabetes // Diabetologia. - 2009. - Vol. 52, N 7. P. 1274-1278.

14. Dangle P. P., Ayyash O., Kang A. et al. Cystatin C-calculated glomerular filtration rate-a marker of early renal dysfunction in patients with neuropathic bladder // Urology. - 2017. - Vol. 100. P. 213-217.

15. Derzhko R., Plaksej R., Przewlocka-Kosmala M., Kosmala W. Prediction of left ventricular dysfunction progression in patients with a first $S T$-elevation myocardial infarction-contribution of cystatin C assessment // Coron. Artery Dis. - 2009. - Vol. 20, N 7. - P. 453-461.

16. Dharnidharka V.R., Kwon C., Stevens G. Serum cystatin C is superior to serum creatinine as a marker of kidney function: a meta-analysis // Am. J. Kidney Dis. - 2002. - Vol. 40, N 2. - P. 221-226.

17. Djousse L., Kurth T., Gaziano J. M. Cystatin C and risk of heart failure in the physicians health study (phs) // Am. Heart. J. - 2008. - Vol. 155. - P. 82-86. 
18. Dzielinska Z., Januszewicz A., Wiecek A. et al. Reduced kidney function estimated by cystatin C and clinical outcomes in hypertensive patients with coronary artery disease: association with homocysteine and other cardiovascular risk factors // Kidney Blood Press Res. - 2010. - Vol. 33, N 2. - P. 139-148.

19. Filler G., Bokenkamp A., Hofmann W. et al. Cystatin C as a marker of GFR - history, indications, and future research // Clin. Biochem. - 2005. - Vol. 38, N 1. - P. 1-8.

20. Ge C., Ren F., Lu S., Ji F. et al. Clinical prognostic significance of plasma cystatin C levels among patients with acute coronary syndrome // Clin. Cardiol. - 2009. - Vol. 32, N 11. - P. 644-648.

21. Hoke M., Amighi J., Mlekusch W. et al. Cystatin C and the risk for cardiovascular events in patients with asymptomatic carotid atherosclerosis // Stroke. - 2010. - Vol. 41, N 4. - P. 674-679.

22. https://www.kidney.org/professionals/KDOQI/gfr_calculatorPed.

23. Ichimoto E., Jo K., Kobayashi Y. et al. Prognostic significance of cystatin C in patients with STelevation myocardial infarction // Circ. J. - 2009. - Vol. 73, N 9. - P. 1669-1673.

24. Jeon Y. K., Kim M. R., Huh J. E. et al. Cystatin C as an early biomarker of nephropathy in patients with type 2 diabetes // J. Korean. Med. Sci. - 2011. - Vol. 26, N 2. - P. 258-263.

25. Jernberg T., Lindahl B., James $S$. et al. Cystatin C: a novel predictor of outcome in suspected or con- firmed non-ST-elevation acute coronary syndrome // Circulation. - 2004. - Vol. 110, N 16. - P. 2342-2348.

26. Keller T., Messow C. M., Lubos E. et al. Cystatin C and cardiovascular mortality in patients with coronary artery disease and normal or mildly reduced kidney function: results from the AtheroGene study // Eur. Heart J. - 2009. - Vol. 30, N 3. - P. 314-320.

27. Kidney Disease: Improving Global Outcomes (KDIGO) CKD Work Group. KDIGO 2012 Clinical Practice Guideline for the for the Evaluation and Management of Chronic Kidney Disease // Kidney inter. - 2013. - Vol. 3. - P. 1-150.

28. Kilic T., Oner G., Ural E. et al. Comparison of the long-term prognostic value of cystatin C to other indicators of renal function, markers of inflammation and systolic dysfunction among patients with acute coronary syndrome // Atherosclerosi. - 2009. - Vol. 207, N 2. - P. 552-558.

29. Lee M., Saver J. L., Huang W. H. et al. Impact of elevated cystatin C level on cardiovascular disease risk in predominantly high cardiovascular risk populations: a meta-analysis // Circ. Cardiovasc. Qual. Outcomes. - 2010. - Vol. 3, N 6. - P. 675-683.

30. Maahs D. M., Snell-Bergeon J. K., Hokanson J. E. et al. Relationship between cystatin C and coronary artery atherosclerosis progression differs by type 1 diabetes // Diabetes Technol. Ther. - 2010. - Vol. 12, N 1. - P. 25-33.

31. Mareš J., Stejskal D., Vavrauškova J. et al. Use of cystatin C determination in clinical diagnostics // Biomed. Papers. - 2003. - Vol. 147, N 2. - P. 177-180.

32. Melander O., Newton-Cheh C., Almgren P. et al. Novel and conventional biomarkers for prediction of incident cardiovascular events in the community // JAMA. - 2009. - Vol. 302, N 1. P. 49-57.

33. Mena C., Robles N. R., de Prado J. M. et al. Cystatin C and blood pressure: results of $24 \mathrm{~h}$ ambulatory blood pressure monitoring // Eur. J. Intern. Med. - 2010. - Vol. 21, N 3. - P. 185-190.

34. Menon V., Shlipak M. G., Wang X. et al. Cystatin C as a risk factor for outcomes in chronic kidney disease // Ann. Intern. Med. - 2007. - Vol. 147, N 1. - P. 19-27.

35. Mussap M., Plebani M. Biochemistry and clinical role of human cystatin C // Crit. Rev. Clin. Lab. Sci. - 2004. - Vol. 41, N 5-6. - P. 467-550.

36. Nitsch D., Dietrich D. F., von Eckardstein A. et al. Prevalence of renal impairment and its association with cardiovascular risk factors in a general population: results of the Swiss SAPALDIA study // Nephrol. Dial. Transplant. - 2006. - Vol. 21, N 4. - P. 935-944.

37. Okura T., Jotoku M., Irita J. et al. Association between cys- tatin C and inflammation in patients with essential hypertension // Clin. Exp. Nephrol. - 2010. - Vol. 14, N 6. - P. 584-588.

38. Palatini P., Benetti E., Zanier A. et al. Cystatin C as predictor of microalbuminuria in the early stage of hypertension // Nephron. Clin. Pract. - 2009. - Vol. 113, N 4. - P. 309-314.

39. Pedrinelli R., DellOmo G., Penno G. et al. Association of Microalbuminuria with Metabolic Syndromeamong Aged Population // Bio. Med. Research. International. - 2016. - Vol. 6. - P. 226-233.

40. Peralta C. A., Katz R., Sarnak M. J. et al. Cystatin C identifies chronic kidney disease patients at higher risk for complications // J. Am. Soc. Nephrol. - 2011. - Vol. 22, N 1. - P. 147-155.

41. Pottel H., Delanaye P., Schaeffner E. et al. Estimating glomerular filtration rate for the full age spectrum from serum creatinine and cystatin C // Nephrol. Dial. Transplant. - 2017. - Vol. 32, N 3. - P. 497-507.

42. Prats M., Font R., Bardaji A. et al. Cystatin C and cardiac hypertrophy in primary hypertension // Blood Press. - 2010. - Vol. 19, N 1. - P. 20-25. 
43. Rifkin D. E., Katz R., Chonchol M. et al. Albuminuria, impaired kidney function and cardiovascular outcomes or mortality in the elderly // Nephrol. Dial. Transplant. - 2010. - Vol. 25, N 5. P. 1560-1567.

44. Ronco C., McCullough P., Anker S. et al. Cardio-renalsyndromes: reportfrom the consensus conference of the Acute Dialysis Quality Initiative // Eur. Heart. J. - 2010. - Vol. 31. - P. 703-711.

45. Sahakyan K., Klein B. E., Lee K. E. et al. Serum cystatin C and the incidence of hypertension in type 1 diabetes mellitus // Am. J. Hypertens. - 2011. - Vol. 24, N 1. - P. 59-63.

46. Shankar A., Teppala S. Relationship between serum cystatin C and hypertension among US adults without clinically recognized chronic kidney disease // J. Am. Soc. Hypertens. - 2011. Vol. 16. - P. 378-384.

47. Sherief L. M., Youssef D. M., Sherbiny H. S. et al. Screening of renal dysfunction among Burkitt lymphoma survivors by novel markers // Hematology. - 2017. - Vol. 22, N 5. - P. 265-273.

48. Taglieri N., Fernandez-Berges D. J., Koenig W. et al. Plasma cystatin C for prediction of 1-year cardiac events in Mediterranean patients with non-ST elevation acute coronary syndrome // Atherosclerosis. - 2010. - Vol. 209, N 1. - P. 300-305.

49. Watanabe S., Okura T., Liu J. et al. Serum cystatin C level is a marker of end-organ damage in patients with essential hypertension // Hypertens Res. - 2003. - Vol. 26, N 11. - P. 895-899.

50. Windhausen F., Hirsch A., Fischer J. et al. Cystatin C for enhancement of risk stratification in non-ST elevation acute coro- nary syndrome patients with an increased troponin $\mathrm{T} / / \mathrm{Clin}$. Chem. - 2009. - Vol. 55, N 6. - P. 1118-1125.

51. Wu C. K., Chang M. H., Lin J. W. et al. Renal-related biomarkers and long-term mortality in the US subjects with different coronary risks // Atherosclerosis. - 2011. - P. 226-236.

52. Zhang P. P., Zhan J. F., Xie H. L. et al. Evaluation of glomerular filtration rate using cystatin $\mathrm{C}$ in diabetic patients analyzed by multiple factors including tubular function // J. Int. Med. Res. 2010. - Vol. 38, N 2. - P. 473-483.

53. Zhu Z., Zhong C., Xu T. et al. Prognostic significance of serum cystatin $\mathrm{C}$ in acute ischemic stroke patients according to lipid component levels // Atherosclerosis. - 2018. - Vol. 274. - P. 146-151.

\section{ДІАГНОСТИЧНЕ ТА ПРОГНОСТИЧНЕ ЗНАЧЕННЯ ЦИСТАТИНУ С ЯК РАННЬОГО МАРКЕРА НИРКОВОЇ ДИСФУНКЦІЇ У ХВОРИХ ІЗ СЕРЦЕВО-СУДИННОЮ ПАТОЛОГІЕЮ}

\section{Н. В. Кузьмінова, А. В. Іванкова, В. П. Іванов, С. Е. Лозинський (Вінниця)}

При серцево-судинних захворюваннях досить часто виникає порушення функції нирок, що має із серцем складні гемодинамічні та нейроендокринні зв'язки. В статті розглянуто будову, функції та можливості застосування ендогенного індикатора функціонального стану нирок цистатину С. Дані літератури дозволяють використовувати цистатин С як предиктор ниркової дисфункції у хворих із серцево-судинною патологією, зокрема артеріальну гіпертензію. Проте широке застосування цистатину С в рутинній клінічній практиці потребує подальшого вивчення та удосконалення.

Ключові слова: цистатин C; швидкість клубочкової фільтрації; креатинін; кардіоренальний синдром; кардіоваскулярний ризик; серцево-судинна патологія; серцева недостатність; інсульт; ішемічна хвороба серця; цукровий діабет; артеріальна гіпертензія.

\section{ДИАГНОСТИЧЕСКОЕ И ПРОГНОСТИЧЕСКОЕ ЗНАЧЕНИЕ ЦИСТАТИНА С КАК РАННЕГО МАРКЁРА ПОЧЕЧНОЙ ДИСФУНКЦИИ У БОЛЬНЫХ С СЕРДЕЧНО-СОСУДИСТОЙ ПАТОЛОГИЕЙ}

\section{Н. В. Кузьминова, А. В. Иванкова, В. П. Иванов, С. Э. Лозинский (Винница)}

При сердечно-сосудистых заболеваниях довольно часто возникает нарушение функции почек, которые имеют с сердцем сложные гемодинамические и эндокринные связи. В статье рассмотрены строение, функции и возможности применения эндогенного индикатора функционального состояния почек - цистатина С. Имеющиеся данные позволяют использовать цистатин С как предиктор почечной дисфункции у больных с сердечно-сосудистой патологией, в частности артериальной гипертензией. Тем не менее широкое использование цистатина $\mathrm{C}$ в рутинной клинической практике требует дальнейшего изучения и усовершенствования.

Ключевые слова: цистатин C; скорость клубочковой фильтрации; креатинин; кардиоренальный синдром; кардиоваскулярный риск; сердечно-сосудистая патология; сердечная недостаточность; инсульт; ишемическая болезнь сердца; сахарный диабет; артериальная гипертензия. 